\title{
Exploration of the Impact of Teacher Training on Teacher Professional Development
}

\author{
Cui Jingjing \\ Jilin Business and Technology College \\ P.R.China, 130507 \\ 107851252@qq.com
}

\begin{abstract}
From the perspective of teacher professional development, this paper have an overview of the status quo of foreign language teachers' professional development and difficulties, which combined with different aspects of Teachers' Professional Development to analyze the Teachers in training and summarized the important role of teacher professional development. At the same time, we explore how to promote professional development of teachers and enhance the cultivation of teachers' training and find out three main ways of college English teachers' professional development. Thereby it presents a reference for learning English as a way of professional development of teachers.
\end{abstract}

Keywords-Teacher Training;status quo; foreign language teachers; Teachers' Professional Development

\section{INTRODUCTION}

Education plans, teacher-centered. There are good teachers, there is a good education. In all the process of education reform, teacher always played a very important role and the teacher quality directly affects the effectiveness of reforms. The teacher education and development is essential (Roge two 2003; Fullan2007; WU Yi'an 2008)[6][8]. College English teaching reform is inseparable from the high-quality teachers and teachers are the key factor of implementing the reform program. Therefore, it is a research topic of great practical significance that how to improve the quality of foreign language teachers self-development through systematic training and development of teachers and cooperation among teachers; it is an insurance that the smooth implementation of the reform of college English teaching and foreign language teachers to meet the lifelong career development. Bailey et al. (2001) pointed out that a qualified teacher not only need to have the basic theoretical knowledge of pedagogy, psychology and other fields, but also in addition to having the basic skills of a subject have to apply these theories to practice their ability. [4]Teachers are the main practitioners and facilitator of school education. Quality of teachers, in a sense, is relation to these groups a nation or a country's success or failure. Currently, teachers' development is a grim unavoidable problem faced by our country which is how to fundamentally improve the ability of teachers to meet the needs of national development. Teachers have cognitive theory, teaching ability, teaching experience, teaching methods and strategies, which is the essence of psychological theory - metacognition. In essence, this process is a kind of meta-cognitive process which is also implicit teachers' own growth and improvement. To strengthen the opportunities of teachers training can promote teachers' professional development.

\section{STATUS QUO AND DILEMMA OF ForEIGN LANGUAGE TEACHER PROFESSIONAL DEVELOPMENT}

In recent years, with the deepening of reform and opening up and international exchanges frequently, a broad range applications of English is more important than ever before, the level and style of education has also been an unprecedented development. English teachers as a commitment to education and training are also showing a more diverse development. In this situation, we need to think about some problems seriously, such as what are the features of English teacher development? And whether or not their professional identity and career planning have adaptation with reality, and how to enhance and improve the English teacher development. Jiang Yumei (2012) [3]have made an analysis on the status quo and influencing factors of College English Teachers' professional development. The results show that the current structure of English teachers unbalanced, which showed a kind of pattern, namely: more female teachers, less male teachers; more young teacher, less experienced teachers; more intermediate grade, less senior; Masters much less doctor. Literacy teachers' imbalance is reflected as "strong teaching, weak scientific research." In teacher training, most teachers lack of training opportunities and opportunities to study abroad is even more rare. It shows that $73.9 \%$ of the teachers did not participate in study abroad. However, it cannot be optimistic that English teachers participate in international academic conferences. During the five years, $49.6 \%$ of English teachers did not participate in domestic academic conferences. $78.5 \%$ of English teachers never participate in international academic conference. In addition, many English teachers lack of clear planning and a professional identity and career loyalty crisis in some degrees on their own career development prospects. It is worth that the English teacher not only bring confusion comes from the profession itself on the road of professional development, but also come from the constantly changing social environment. Specifically, there are two changes need particular attention. First, with the improvement of English education in primary and secondary school level, the Ministry of Education made it clear in 2017 to promote foreign language exam formal social reform, that is, students take the exam to have more opportunities a year and they choose the exam time and frequency autonomously. Secondly, English Education transforms from basic English to professional which force the 
English teachers should have a certain professional disciplines background as a support in order to cultivate the compound talents to adapt to the international development. However, in the past, it is difficult to adapt to the new situation which focused on skills-based training objectives. In the terms of English major, the three types of talents (i.e. complex, bilingual type and main and auxiliary personnel) are cultivated in the last 20 years which become the main flows of China's English Teaching Reform (Hu Wenzhong, Sun youzhong 2006: 243)[7]. English is a tool reflects more value, and professionalism is being more and more attention, namely English language teachers, in addition to expertise, must prepare for broadening their own career development path, which is no doubt they need the knowledge and professionalism of reserves.

\section{The Main Ways of College English Teachers' PROFESSIONAL DEVELOPMENT}

\section{A. Strengthen Teacher Training and Promote Teacher Professional Development}

Some scholars have discussed to the quality of Foreign Language Teachers. We believe that qualified foreign language teachers should meet the following criteria: good character; good basic skills in foreign languages; extensive knowledge such as linguistics, pedagogy, psychology knowledge; good classroom control and good teaching methods. Foreign language teachers should have criteria above and need to strengthen vocational training which leads to promote professional development. On the one hand, education authorities should take active measures to create training for teachers, learning opportunities, such as regularly provide short-term training courses for teachers in the university education; create conditions at home and abroad to study; encourage teachers to actively participate in seminars at home and abroad and encourage teachers to pursue doctorate, etc.; and help them to enrich and update foreign language teaching theory, strengthen language skills, expand knowledge and improve research capacity and teaching effectiveness. On the other hand, education authorities should correctly guide the professional development of teachers, and encourage teachers to cultivate self-improvement, career development consciousness for lifelong learning. This self-awareness development is particularly important because teachers are the subject of career development and self-development and selfimprovement are stimulated by their internal requirements. Action based on teacher self-reflection is an effective way of self-professional development of teachers. Action research is to study the problems in the classroom teaching, through observation, reflection and systematic analysis, to find solutions to problems, to achieve the purpose of improving teaching methods and teaching effectiveness. This research method is particularly suitable for the majority of the heavy task of foreign language teachers. Firstly, we can improve teaching effectiveness by addressing the practical problems of classroom teaching. Secondly, it can also enhance the research capacity of teachers and promote professional development. Teacher professional development is a long-term and dynamic process. School administrators' concept, policy and human environment is the external factors of College English
Teachers' Professional Development. Healthy and positive local environment will inspire their career development. On the contrary, hinder its development. It is an important external factor to encourage teachers' professional development to create a good physical condition for teachers such as caring and encouraging their growth, creating a healthy competitive environment of teamwork and ensuring that they have the time and energy to carry out professional development. A favorable external environment can ensure that teachers develop teaching metacognitive activities, promote teacher in a good environment to continue to reflect progress, and actively carry out career development. Of course, from a broader perspective, the professional development of English teachers is also concerning a reform of the education system and educational ideas. Therefore, we need have overall consideration. At the social level, education departments, publishing houses and academic institutions were established by teachers co-annual (domestic and foreign) training program which focused on the professional direction targeted system training for English teachers who lacks of professional direction knowledge. At the school level, it should give priority to cultivate teachers in the way of school-based and supplemented by the way outside. Comprehensive university is rich in resources. We can consider providing series of training courses for English teachers in view of making use of other colleges' resources, so that help English teachers professional orientation. Foreign language college and university English teaching departments can work together to provide English language training for teachers of other colleges. We solve the shortage of Bilingual teacher through building the mutual platform. And schools not only can provide more convenient training options for teachers through the online classroom, virtual learning communities and other ways, but also can build a more personalized learning platform for them by establishing win-win cooperation between different modes of professional teachers. In addition, in order to improve the professionalism of teachers of English, the school also carried out training programs for various types of cooperation, namely cooperation between the different levels of universities, cooperation between domestic and foreign universities and so on.

\section{B. The Teaching Is Fundamental, Research Is the Key}

On terms of university teachers, pedagogue is not a good teacher who has both the conduct of the teaching and a physical way of scientific research. Teacher Research innovation is an effective way to enhance their professional qualities, and inevitable choice to improve talent ability. Research involved in teaching and learning will have a positive interaction, which will not only allow students to get a better opportunity to learn and benefit from, but also continue to improve the quality of teachers, and gradually become an expert in this field! Research itself is not only a high efficiency of Teaching form, but also an active learning model. Research is the integration of teaching and learning tools. To establish Research - Teaching - Learning Connection Body at the University is the "significant secret" in the university laboratory, humanities and social sciences research and efficient operation. Sense of self-development and the pursuit of excellence in the spirit of the teachers are the driving force 
of the achievements of outstanding teachers, which means that teachers first need to be responsible for their own professional development. Teachers should have a more intense sense of ownership that teachers should be the masters of their own professional development. Research is the support and extension of teaching. English teachers need to carry out personal development and professional development simultaneously to achieve its longitudinal career development. Scientific research and teaching practice provide firsthand such as ideas, information, and other issues and inspiration and so on for research which injects new elements of scientific research; in turn, it also serves for teaching which is full of vitality and wisdom; at the same time, it can be tested through this platform. Teachers must first be learners and teachers' self-development is a prerequisite for independent learning. Practical knowledge of individual teachers filtrated and guided by teachers to accept information outside. English subject knowledge and teaching skills knowledge is an essential element within the framework of foreign language teachers professional qualities (WU Yi'an, 2005) [6], and Teacher practical knowledge is the key to the effectiveness of the former! Outstanding foreign language teachers combines the teaching objectives in education and guidance and the organic integration of these three types of knowledge in the teaching process to better follow the holographic memory and the switching mechanism. The only difference between the dynamic update features will be converted to the subjective and objective valid information and characterize the unique personality of the students to demonstrate creativity. It can stimulate student learning interest and students start thinking which led to effective learning. The difference of "Pedagogue" and "Educator" lies in: the former is only to carry obsolete knowledge for students, while the latter was fresh and tasty knowledge for students. Construction of Foreign Language Teachers body practical knowledge system is the basic premise of starting teaching and research from the "spontaneous" to "conscious" and foreign language teachers generate individualized teaching discourse and harness the power of teaching effectively in essence.

\section{Expand Ways of Teaching and Update Educational Philosophy}

It is the only way that the English Teachers' Professional Development to Select the appropriate professional direction. To achieve this goal, teachers must make full and long-term mental preparation and constantly update the concept of career development, make a clear understanding of the status quo and trends in career development, enhance the sense of actively. Finally, we should carry out career planning, such as upgrading their qualifications, attending academic conferences, undergoing training and other means are available for selection. Today is the era of rapid development of Internet; various educational resources must be shared. English teachers can take advantage of the Internet to obtain professional core curriculum multi-modal data and have a long-term system of learning in order to realize a new way to develop their own career development. The major portals are not difficult to find a wide variety of domestic and foreign famous universities open courses. If you complete the corresponding course, you can get the relevant certificate. These resources for teachers' professional development have provided favorable conditions. In order to test the degree of professionalism of teachers, the school can develop relevant assessment criteria to evaluate the professional level of teachers; they may be allowed full English teaching professional direction of curriculum assessment by teachers.

\section{CONCLUSION}

If teachers improve their teaching level and ability, realize themselves constantly reflect on their own teaching process, adhere to actively self-reflection and practice, they will expand their professional horizons, develop reflection habits gradually, and establish mechanisms for self-reflection. Ultimately they can promote their professional development. Teachers training can helps teachers to cultivate "selfrenewal" capability and enhance teaching effectiveness and efficiency of teachers which not only improve teaching practical exercise capacity, but also constantly replenished a rich, developed and refined improvement through teacher training. We now focus on the quality of education and ability and teachers improve themselves to better analyze, discuss and solve problems that encountered in the teaching process. In short, the professional development of English teachers are by means of external platform develops scientific career development planning and pays attention to teacher training. Thereby it provides a reference for learning English as a way of professional development of teachers.

\section{Teaching Reflection}

The waste is not known, the line without thinking is lazy! Teaching reflection consciously make ordinary teachers to become expert teachers (Russel \& Korthagen, 1995).[2] Teaching reflection is the basic premise of innovation of teaching and research and the only way the growth of teachers. There is no reflection; there is no sustainable teacher development. First, we should reflect on language teaching experience, particularly the strengthening of their own foreign language classroom teaching practices effectiveness! Individual teacher has their own teaching commonsense understanding for teaching experience. It is the teacher's own subjective value judgments come from teaching activities and educational events. It has a non-critical idea (Chen Jianhua, 2012) and the characteristics of the structure and function of autonomy. Therefore, it will consciously safeguard education Subject prejudice which arises from the exclusion of other points of view and impedance. We can share teaching reflection and exchanges to breakthrough experiences their narrowness so as to form rational consciousness of teaching. At the same time, the most important matter is that really valuable part can guide teaching in order to more effectively mining, consolidation and promotion of our teaching practice and get better development in the limited time for students! Therefore, deliberative resourceful and objective evaluation of the actual teaching effectiveness can operate of the legality of observation in order to form appropriate localization of foreign language teaching concepts and effective teaching of practical wisdom. 


\section{REFERENCES}

[1] Flavell J H. Metacognition and cognitive monitoring: A new area of cognitive-developmental inquiry[J]. American Psychologist, 1979, (34): 906-911

[2] [Russel , T.\&F.Kathagen, 1995.Teachers Who Teach Teachers: Reflections on teacher education. Routlede:Falmer Press.

[3] Wang Ping, Wang Weiping.The core of college foreign language teachers' professional development and effective way [J].Chinese school education,2012,(1): p56 57. (In Chinese)

[4] Jiangyumei.Career Development Situation of College English Teachers and Influencing Factors[J]. Chinese Language,2012.7.(In Chinese)

[5] .Bailey,K.M.,Curtis,A.\&Numan,D.PursuingProfessionalDevelopment:T heSelfasSource[M].Boston:Heinle \&2001:22
[6] Liu ruiqing,,Daimanchun.Chinese College English Teaching: Current Situation and Development Strategies [M].Beijing: Foreign Language Teaching and Research Press, 23. (In Chinese)

[7] Wu yi'an. Outstanding Foreign Language Teachers' Professional Quality Inquiry. [J] Foreign Language Teaching and Research Press, 2005, (3) . (In Chinese)

[8] Hu Wen zhong, Sun Youzhong. Prominent subject Strengthening humanistic education: Teaching Reform of Current English [J].Foreign Teaching and Research, 2006(5). (In Chinese)

[9] [8].Chen Tangyan,Zengjie. Foreign Language Teaching metacognitive Ability Review [J].Foreign language,2007, 2.(In Chinese) 